\title{
Pengelolaan Arsip Di Sekolah Tinggi Ilmu Hukum Sumpah Pemuda Palembang
}

Vivi Indriani, Yuandita Armelia, dan Guntur Pratama M.P

\begin{abstract}
This article discusses about how the condition of archives at Palembang Youth Planning Law School and how the process of managing the archives. This study aims to determine the condition of archives and archive management process. The research method using quantitative is by conducting intensive interviews. The results show that the condition of the archive today can not be said perfect because there are still many that do not fit with as it should. The management of archives at Palembang Youth Planning Law School can be said is not good enough, it can be seen from the management, storage, maintenance and depreciation of the archive that has not been maximized in the implementation. And human resources are still lacking and the background of the head of management is not an archivist but in the field of law.
\end{abstract}

Keywords: Filing Unit, Archive Management, University Archive

\section{Pendahuluan}

Informasi menjadi kebutuhan sangat penting bagi setiap organisasi, salah satunya Perguruan Tinggi sebagai lembaga pendidikan. Setiap pekerjaan dan kegiatan organisasi memerlukan data dan informasi. Untuk kemajuan suatu organisasi memerlukan dukungan manajemen yang tepat, sehingga memerlukan data dan informasi. Salah satu sumber data adalah arsip, karena arsip adalah bukti dan rekaman kegiatan transaksi mulai dari kegiatan sampai akhir. Arsip-arsip tersebut digunakan baik untuk keperluan intern. Arsip akan memberikan nilai manfaat yang banyak jika keberadaannya mampu dikelola dengan baik, efektifitas dan efensiensi dalam penggunaannyapun dapat disajikan dengan optimal. Oleh karena itu, informasi menjadi bagian yang sangat penting untuk mendukung suatu Perguruan 
Tinggi dalam menghadapi semua perubahan situasi dan kondisi yang semakin berkembang dengan cepat.

Salah satu sumber informasi penting yang dapat menunjang perubahan situasi dan kondisi yang berkembang dengan cepat adalah arsip. Arsip dapat digunakan sebagai sumber informasi untuk mengingatkan mengenai suatu masalah dan sebagai sumber dokumentasi untuk membuat serta mengambil keputusan secara tepat mengenai suatu masalah yang sedang dihadapi. Oleh karena itu, arsip perlu adanya pengelolaan agar keberadaan arsip tersebut terjaga dari penciptaan sampai dengan penyusutan (Alvyanti, 2015). Dalam Undang-undang Republik Indonesia No 43 Tahun 2009 tentang Kearsipan yaitu rekaman kegiatan atau peristiwa dalam berbagai bentuk dan media sesuai dengan perkembangan teknologi informasi dan komunikasi yang dibuat dan diterima oleh lembaga negara organisasi kemasyarakatan, dan perseorangan dalam pelaksanaan kehidupan bermasyarakat, berbangsa, dan bernegara. Disamping itu kami melakukan penelitian di Sekolah Tinggi Ilmu Hukum Sumpah Pemuda yang bertujuan untuk mengetahui bagaimana cara pengelolaan arsip dari penciptaan sampai penyusutan.

Sekolah Tinggi Ilmu Hukum Sumpah Pemuda adalah sebuah perguruan tinggi swasta di Kota Palembang. Perguruan tinggi yang program studinya berfokus tentang ilmu hukum ini didirikan pada tanggal 28 Oktober 1994 yang memiliki struktur organisasi yang salah satunya itu bagian bidang kearsipan, pada bagian bidang kearsipan dibagi lagi menjadi tiga fungsi yaitu bagian administrasi, bagian pengelolaan data dan bidang kearsipan.

Pada bidang kearsipan ini data berkas laporan arsip yang masuk dari instansi lain, datanya dikelola secara manual, sehingga proses pencarian arsip baik yang baru masuk maupun yang arsip yang sudah lama yang membuat kurangnya pengefisiensian waktu. Arsip dinamis yang sudah waktunya lima 
tahun menjadi arsip statis yang akan dipindahkan di gudang arsip untuk disimpan karena sudah jarang digunakan.

Berdasarkan penelitian yang dilakukan bahwa pengelolaan arsip inaktif di Sekolah Tinggi Ilmu Hukum Sumpah Pemuda masih belum opimal. Ada beberapa hal yang menyebabkan pengelolaan arsip inaktif belum optimal yaitu salah satu fasilitas penyimpanan arsip inaktif berupa ruang penyimpanan belum memenuhi standar. Dalam pengelolaan arsip inaktif ini disimpan di gudang arsip yang tidak memiliki perawatan khusus hanya saja dibersihkan kotoran atau debu-debu. Dan arsip inaktif yang sangat penting akan digitalisasikan. Sedangkan untuk menyusutan dan pemusnahan belum dilakukan di Lembaga ini jadi hanya disimpan terus-menerus sampai gudang tersebut terpenuhi.

Salah satu hal yang terpenting dalam pengelolaan arsip adalah sumberdaya manusia pengelola arsip. Tenaga arsiparis harus cermat dan rajin sehingga arsip yang semakin bertambah banyak dapat dikelola dengan baik dan tidak menyebabkan penumpukan arsip. Arsip-arsip yang tertumpuk dan tidak teratur akan menyebabkan arsip sulit ditemukan ketika sewaktu-waktu dibutuhkan. Pada lembaga ini pengelolaan arsip dinamis terkendala pada sumber daya pengelola arsip yaitu hanya ada satu sumber daya yang mengelola arsip di lembaga ini yang latar belakangnya bukan seorang arsiparis tetapi seorang dibidang hukum. Oleh sebab itu akan dikaji lebih dalam lagi tentang bagaimana "Pengelolaan Arsip Pada Sekolah Tinggi Ilmu Hukum Sumpah Pemuda di Kota Palembang"

Rumusan Masalah

Berdasarkan latar belakang diatas, maka peneliti perlu merumuskan masalah dalam penelitian ini. Adapun rumusan masalah dalam penelitian ini adalah sebagai berikut : 
1. Bagaimana kondisi arsip pada Sekolah Tinggi Ilmu Hukum Sumpah Pemuda?

2. Bagaimana proses pengelolaan Arsip pada Sekolah Tinggi Ilmu Hukum Sumpah Pemuda Palembang?

\section{Pembahasan}

Universitas Sekolah Tinggi Ilmu Hukum Sumpah Pemuda Palembang memiliki berbagai bentuk arsip yang sangat penting sebagai pembuktian hasil kegitan yang dilakukan untuk menunjang akreditasi dikemudian hari. Sekolah Tinggi Ilmu Hukum Sumpah Pemuda ini didirikan atas prakarsa dari (Alm) Prof. H. Abu Daud Busroh, SH, yang merupakan salah satu tokoh masyarakat, penengak hukum dan akademisi hukum yang ternama baik ditingkat Daerah maupun Nasional. STIHPADA didirikan berdasarkan Akta Pendirian No. 88 tgl. 28 Oktober 1994 Jo. No. 24 tanggal 10 November 1995 dihadapan Notaris Fauzi, SH. Dengan berbekal tekad, semangat dan pengorbanan materi, beliau mendirikan STIHPADA di 8 Ulu Palembang dan kemudian di tahun 2014 STIHPADA pindah di Jln. Sukabangun 2 No. 1610 Kota Palembang Prov. Sumatera Selatan.

Sekolah Tinggi Ilmu Hukum Sumpah Pemuda terdiri atas tiga kelompok fungsional, yaitu kelompok pengajar atau pendidik (staff educative), kelompok mahasiswa, dan kelompok tenaga nonedukatif. Kelompok terakhir ini terdiri atas pegawai teknik, pegawai tata usaha dan keuangan, tenaga pengelola kearsipan, serta karyawan non-spesifik.

Menurut (Sutarto, 1997) arsip merupakan sekumpulan warkat yang memiliki nilai guna tertentu yang disimpan secara sistematis dan setiap saat diperlukan dapat ditemukan kembali dengan cepat.

Undang-Undang Republik Indonesia No 43 Tahun 2009 tentang Kearsipan yaitu rekaman kegiatan atau peristiwa dalam berbagai bentuk dan media sesuai dengan perkembangan 
teknologi informasi dan komunikasi yang dibuat dan diterima oleh lembaga negara organisasi kemasyarakatan, dan perseorangan dalam pelaksanaan kehidupan bermasyarakat, berbangsa, dan bernegara.

Menurut (Barthos, 2007) Kearsipan merupakan suatu hal yang penting bagi setiap organisasi untuk menunjang setiap kegiaran yang dilakukan. Arsip itu digunakan sebagai salah satu sumber informasi, pusat ingatan, melakukan perencanaan sebagai alat untuk membantu pengambilan keputusan, maupun sebagai penunjang bagi ketertiban administrasi.

Arsip merupakan catatan sebagai memori kolektif keberadaan suatu lembaga atau Institusi. Melalui catatan itulah kini dapat tergambar perjalanan panjang sejarah keberadaan suatu lembaga dari waktu ke waktu. Kita tidak akan pernah tahu peristiwa apa yang pernah terjadi di masa lalu, tanpa melihat warisan catatan sebagai memori kolektif yang merupakan identitas, harkat dan perwujudan aktivitas sebuah lembaga. Memori yang tertulis dalam arsip dan sebentuk fakta selalu dapat disimak masa kini dan diwariskan kepada generasi di masa yang akan datang.

Arsip dapat dibuat dan diterima suatu organisasi seiring dengan aktivitas dan dinamika suatu lembaga. Seiring dengan berjalannya waktu dan juga banyak kegiatan yang telah dilakukan pada suatu lembaga, maka makin banyak pula arsip yang tercipta. Apabila arsip didiamkan begitu saja tanpa dikelola maka akan menyita tempat, tenaga, dan waktu, serta informasi yang bersifat penting pun dapat hilang.

Kurangnya pengelolaan arsip dapat mengakibatkan penemuan kembali arsip sulit dilakukan secara cepat dan bertambahnya arsip seiring dengan aktivitas suatu lembaga yang tidak diikuti dengan penyimpanan yang sistematis akan berakibat pada penumpukan arsip. Jika penumpukan arsip terjadi secara 
terus menerus tanpa ada pengelolaan yang tepat, maka akan membuat keadaan fisik arsip rusak sehingga sulit dikenali.

Bertambahnya arsip secara terus menerus juga dapat mengakibatkan tempat penyimpanan arsip tidak mencukupi. Tidak mencukupinya tempat penyimpanan dapat terjadi karena sistem penyusutan arsip tidak berjalan secara teratur, tempat penyimpanan arsip digunakan untuk menyimpan barang-barang selain arsip, dan ruang penyimpanan arsip yang terlalu kecil. Selain itu juga dapat diakibatkan karena kurangnya pembiayaan dalam pengadaan fasilitas pengelolaan arsip.

\section{Kondisi Arsip di Sekolah Tinggi Ilmu Hukum Sumpah Pemuda}

Kondisi arsip saat ini yaitu arsip belum menjadi rujukan pengguna atau mahasiswa sebagai sumber informasi, belum optimalnya fungsi unit kearsipan pada Sekolah Tinggi Ilmu Hukum Sumpah Pemuda, belum terpenuhinya jumlah ideal pejabat fungsional arsiparis bahkan hanya ada 1 orang yaitu Bapak Andi Chandra, M.Hum. Bapak Andri Chandra ini bukan latar belakang arsiparis melainkan dibidang hukum, masih rendahnya kualitas sumber daya manusia kearsipan, bidang kearsipan belum memanfaatkan teknologi dan informasi secara optimal. Adapun Jenis-jenis arsip di Sekolah Tinggi Ilmu Hukum Sumpah Pemuda yaitu: (Andi Chandra, wawancara, 14 Mei 2018)

1. Arsip surat masuk dan surat keluar dari instansi atau lembaga lain

2. Surat hasil kegiatan Sekolah Tinggi Ilmu Hukum Sumpah Pemuda.

3. Arsip nilai akhir semester mahasiswa.

4. Arsip Berkas S2

5. Arsip BPJS

6. Arsip Beasiswa

7. Arsip Surat Tugas 
8. Arsip Kompre, d1l

\section{Pengelolaan Kearsipan}

Pengelolaan arsip merupakan kegiatan pencatatan, penyimpanan, dan pemeliharaan surat atau warkat yang mempunyai arti penting baik ke dalam maupun ke luar, baik menyangkut soal pemerintahan maupun bukan soal pemerintahan dengan menerapkan kebijaksanaan dan sistem tertentu yang dapat dipertanggungjawabkan (Barthos, 2007).

Menurut (Wijaya, 2003), tata cara pengelolaan arsip yang sering dikenal dengan tata kearsipan yang terdiri atas kegiatan pengumpulan berkas, penyimpanan, pengklasifikasian, dan penyusutan berkas.

Menurut (Wijayanti, 2000), aktivitas pokok pengelolaan arsip adalah menyimpan warkat, tetapi tujuan yang utama adalah menemukan kembali secara cepat suatu warkat yang disimpan, sehingga untuk keperluan penemuan kembali itulah maka arsip harus diatur dan dipelihara dengan sebaik-baiknya.

Jadi dapat disimpulkan dari pendapat diatas, bahwa pengelolaan arsip merupakan setiap kegiatan menghasilkan sebuah infomasi yang harus dikelola. Oleh karena itu, arsip harus tetap dipelihara dengan sebaik-baiknya dan dapat digunakan dikemudian hari. Pengelolaan arsip di STIHPADA terdapat penciptaan arsip, prosedur penyimpanan arsip, prosedur pemeliharaan arsip, dan prosedur penyusutan arsip.

\section{a) Penciptaan Arsip}

Penciptaan arsip seperti surat dan naskah lainnya, gambar dan rekaman merupakan aktifitas awal dari masa kehidupan arsip, yaitu kegiatan membuat surat dan dokumen atau naskah lain yang diperlukan dalam rangka penyelenggaraan organisasi untuk mencapai tujuan. Penciptaan arsip dapat diartikan sebagai aktifitas membuat rekaman kegiatan atau peristiwa dalam bentuk 
dan media apapun sesuai dengan perkembangan teknologi informasi dan komunikasi.

Penciptaan arsip di Sekolah Tinggi Ilmu Hukum Sumpah Pemuda ini berasal dari surat masuk, surat keluar, nilai akhir semester mahasiswa dan kegiatan-kegiatan lain untuk menunjang akreditasi Sekolah Tinggi Ilmu Hukum Sumpah Pemuda Palembang.

\section{b) Prosedur Penyimpanan Arsip}

Prosedur penyimpanan arsip dibuat untuk menyeragamkan kegiatan penyimpanan arsip agar tertata secara sistemtis guna terwujudnya penemuan kembali arsip yang tepat dan cepat. Adapun prosedur penyimpanan arsip dibuat untuk menyeragamkan kegiatan penyimpanan arsip agar tertata secara sistemtis guna terwujudnya penemuan kembali arsip yang tepat dan cepat. Menurut (Amsyah, 2003), langkah-langkah pekerjaan penyimpanan terdiri dari kegiatan:

a. Pemeriksaan yaitu memeriksa surat untuk memperoleh kepastian bahwa surat yang bersangkutan memang sudah siap untuk disimpan.

b. Mengindeks yaitu menentukan kata tangkap apa surat akan disimpan.

c. Surat akan tersimpan pada map dengan indeks yang sama.

d. Membuat petunjuk silang untuk surat yang memiliki indeks lebih dari satu.

e. Memberi tanda yaitu dengan memberi tanda garis atau lingkaran dengan warna mencolok pada kata tangkap yang sudah ditentukan.

f. Menyortir yakni mengelompokkan surat untuk persiapan penyimpanan.

g. Menyimpan yaitu menempatkan arsip sesuai dengan sistem penyimpanan dan peralatan yang dipergunakan. 
h. Menyimpan kartu kendali pada kotak kartu kendali sesuai kode klasifikasi.

i. Menata arsip sesuai dengan sistem penyimpanan yang telah dipilih.

Menurut Agus Sugiarto (2005) prosedur penyimpanan arsip merupakan langkah-langkah pekerjaan dalam penyimpanan arsip. Adapun langkah-langkah penyimpanan arsip sebagai berikut:

1) Pemeriksaan dengan cara memeriksa setiap lembar surat untuk memperoleh kepastian bahwa dokumen bersangkutan memang sudah siap untuk disimpan.

2) Mengindeks adalah pekerjaan menentukan pada kata tangkap apa surat akan disimpan.

3) Memberi tanda yaitu dengan memberi tanda garis atau lingkaran dengan warna mencolok pada kata tangkap yang sudah ditentukan.

4) Menyortir adalah mengelompokkan surat berdasarkan kata tangkap yang sudah ditentukan. Meletakkan surat sesuai dengan sistem penyimpanan yang digunakan.

Sedangkan nyatanya di Sekolah Tinggi Ilmu Hukum Sumpah Pemuda memiliki prosedur penyimpanan arsip tersendiri sebagai berikut:

1) Pemeriksaan pada STIHPADA sesuai dengan prosedur yang ada yaitu dengan cara memeriksa setiap lembar surat untuk memperoleh kepastian bahwa dokumen bersangkutan memang sudah siap untuk disimpan. Setelah 5 tahun maka arsip tersebut akan di simpan di gudang penyimpanan arsip.

2) Setelah dalam proses pemeriksaan lalu selanjutnya tahap pengindeksan. Seperti di STIHPADA yaitu mengelompokkan arsip nilai akhir semester menjadi satu sesuai dengan subjeknya. 
3) Memberi tanda pada STIHPADA ini tidak diberlakukan karena kurangnya pengetahuan tentang prosedur penyimpanan arsip.

4) Dan pada tahap menyortir di STIHPADA yaitu arsip dikelompokkan berdasarkan subjek pertahun dan disimpan didalam lemari khusus arsip.

c) Prosedur Pemeliharaan Arsip

Menurut (Barthos, 2007) pemeliharaan arsip adalah usaha penjagaan dari musuh arsip. Adapun musuh dan cara penanganannya adalah sebagai berikut:

1) Kelembaban dan kekeringan udara dapat diatasi dengan cara mengatur suhu dengan menggunakan pengatur suhu.

2) Sinar matahari dapat diatasi dengan menyaring sinar matahari agar tidak langsung masuk ke ruangan penyimpanan arsip, seperti menggunakan kaca hijau atau kaca kuning pada jendela ruangan dan menutup ventilasi dengan melapisi kain.

3) Debu dapat diatasi dengan membersihkan ruangan dari debu.

4) Jamur dapat diatasi dengan melakukan fumigasi.

5) Serangga dapat diatasi dengan melakukan pembasmian dengan menggunakan racun serangga.

Langkah-langkah pemeliharaan arsip dilakukan untuk mencegah kerusakan kondisi fisik arsip dari faktor perusaknya seperti debu, cahaya, suhu udara, serangga, dan jamur. Pemeliharaan dilakukan dengan mengatasi faktor perusak arsip seperti mengatur kelembaban udara, mengatur pencahayaan sinar matahari, membersihkan debu, fumigasi, dan pembasmian serangga. Menurut (Madiana, 2004) pemeliharaan arsip adalah segala kegiatan yang berkenaan dengan penjagaan fisik arsip dan wujud arsip agar tidak lekas rusak selama mempunyai nilai guna. Adapun kegiatan mencegah kerusakan arsip sebagai berikut. 
1) Memilih ruangan penyimpanan arsip sejauh mungkin dari daerah industry dan saluran air, serta membuat konstruksi bangunan yang kuat.

2) Mengatur suhu ruangan dengan melengkapi alat pengatur suhu.

3) Ruangan harus selalu bersih dari debu, kertas bekas, putung rokok, ataupun sisa makanan.

4) Menyediakan alat penyemprotan serangga dan penyegar ruangan.

Sedangkan pada kenyataannya di bagian unit pengelolaan kearsipan Sekolah Tinggi Ilmu Hukum Sumpah Pemuda tidak memiliki pemeliharaan khusus untuk arsip, hanya saja dibersihkan dari debu-debu dan kotoran, begitupun di gudang penyimpanan arsip yang tidak memiliki pemeliharaan dan perawatan khusus hanya dibersihkan dari debu dan kotoran oleh staff kebersihan yang ada di STIHPADA tersebut.

\section{d) Prosedur Penyusutan Arsip}

Prosedur penyusutan arsip dibuat untuk menyeragamkan kegiatan penyusutan arsip agar kondisi tempat penyimpanan arsip dapat menyimpan arsip yang dinilai masih berguna bagi lembaga atau organisasi yang memiliki arsip yang banyak. Menurut (Agus Sugiarto, 2005), penyusutan arsip adalah kegiatan pengurangan arsip dengan cara memindahkan, menyerahkan, dan memusnahkan arsip.

Dalam Peraturan Pemerintah Republik Indonesia Nomor 34 Tahun 1979 tentang Penyusutan Arsip, penyusutan arsip adalah kegiatan mengurangi jumlah arsip dengan cara:

a. Penilaian terhadap arsip yang didasarkan pada nilai guna arsip.

b. Penentuan jadwal retensi setelah kegiatan penilaian.

c. Membuat daftar jenis arsip yang akan dipindahkan

d. Membuat berita acara pemindahan arsip. 
e. Membuat daftar pertelaan arsip yang akan dimusnahkan.

f. Membuat berita acara pemusnahan.

g. Mendatangkan saksi dari lembaga kearsipan, seperti Arsip dan Perpustakaan Daerah (ARPUSDA) atau Arsip Nasional Republik Indonesia (ANRI).

Menurut (Nurhadi, 1983) prosedur penyusutan arsip terdiri dari beberapa kegiatan seperti:

a) Penilaian arsip dilakukan dengan memberikan nilai terhadap arsip sesuai dengan pedoman yang digunakan.

b) Pemindahan arsip dilakukan dengan memindahkan arsip ke pusat penyimpanan arsip.

c) Pemusnahan arsip dilakukan dengan menghancurkan bentuk fisik arsip. Sebelum arsip dimusnahkan maka perlu adanya berita acara dan daftar arsip yang dimusnahkan.

Pada kenyataannya pada tahap prosedur penyusutan arsip di STIHPADA, sebagai berikut:

1) Penilaian arsip yang dilakukan oleh kepala pengelola arsip tidak menggunakan pedoman penyusutan arsip melainkan menggunakan kebijakan sendiri yaitu:

a. Jadwal retensi pada arsip surat masuk dan surat keluar ini yaitu dalam jangka waktu 5 tahun, setelah 5 tahun maka akan disimpan di gudang penyimpanan arsip.

b. Pada arsip surat kegiatan Sekolah Tinggi Ilmu Hukum Sumpah Pemuda, sama halnya dengan surat masuk dan surat keluar yaitu dalam 3 tahun dijilid menjadi satu dan setelah 5 tahun maka akan di simpan digudang penyimpanan arsip.

c. Dan pada arsip nilai akhir semester mahasiswa ini disusun dalam 1 tahun setelah itu akan disimpan digudang penyimpanan arsip. 
2) Pemindahan arsip dilakukan dengan memindahkan arsip yang ada di unit pengelolaan ke pusat penyimpanan arsip atau gudang arsip.

3) Pada tahap pemusnahan arsip di STIHPADA ini tidak diberlakukan karena arsip yang masih sedikit jadi arsip tersebut di simpan dan dipindahkan di gudang penyimpanan arsip.

Jadi dapat disimpulkan bahwa pada tahap penyusutan arsip di STIHPADA ini memiliki kebijakan tersendiri dalam penilaian, pemindahan dan pemusnahan. Arsip yang dikelola di STIHPADA ini tidak dimusnahkan melainkan di simpan dan pindahkan digudang penyimpanan arsip.

\section{Kesimpulan}

Berdasarkan hasil observasi bahwa kondisi arsip saat ini yaitu arsip belum menjadi rujukan pengguna atau mahasiswa sebagai sumber informasi, belum optimalnya fungsi unit kearsipan pada Sekolah Tinggi Ilmu Hukum Sumpah Pemuda, belum terpenuhinya jumlah ideal pejabat fungsional arsiparis bahkan hanya ada 1 orang dalam mengelola arsip dan bukan memiliki latar belakang arsiparis, masih rendahnya kualitas sumber daya manusia kearsipan, bidang kearsipan belum memanfaatkan teknologi dan informasi secara optimal.

Proses pengelolaan arsip pada STIHPADA ini sangatlah sederhana dan kurang maksimal dalam mengelola arsip. Pengelolaan arsip ini mulai dari penciptaan arsip sampai penyusutan arsip.

a. Penciptaan arsip

Penciptaan arsip di Sekolah Tinggi Ilmu Hukum Sumpah Pemuda ini berasal dari surat masuk, surat keluar, nilai akhir semester mahasiswa dan kegiatan-kegiatan lain untuk menunjang akreditasi Sekolah Tinggi Ilmu Hukum Sumpah Pemuda Palembang. 
b. Penyimpanan arsip

Penyimpanan arsip di Sekolah Tinggi Ilmu Hukum Sumpah Pemuda memiliki prosedur penyimpanan arsip tersendiri dengan membuat kebijakan sendiri untuk memudahkan pengelola menemukan kembali arsip tersebut.

c. Pemeliharaan arsip

Sedangkan pada kenyataannya di bagian unit pengelolaan kearsipan Sekolah Tinggi Ilmu Hukum Sumpah Pemuda tidak memiliki pemeliharaan khusus untuk arsip, hanya saja dibersihkan dari debu-debu dan kotoran, begitupun di gudang penyimpanan arsip yang tidak memiliki pemeliharaan dan perawatan khusus hanya dibersihkan dari debu dan kotoran oleh staff kebersihan yang ada di STIHPADA tersebut.

\section{d. Penyusutan arsip}

Bahwa pada tahap penyusutan arsip di STIHPADA ini memiliki kebijakan tersendiri dalam penilaian, pemindahan dan pemusnahan. Arsip yang dikelola di STIHPADA ini tidak dimusnahkan melainkan di simpan dan pindahkan digudang penyimpanan arsip.

\section{Daftar Pustaka}

Agus Sugiarto, T. W. (2005). Manajemen Kearsipan Modern dari Konvensional ke Basis Komputer. Yogyakarta: Gava Media.

Alvyanti, D. P. (2015). Pengelolaan Arsip Sma Negeri Di Kota Yogyakarta. Yogjakarta: Universitas Negeri Yogyakarta.

Amsyah, Z. (2003). Manajemen Kearsipan. Jakarta: Gramedia Pustaka Utama.

Barthos, B. (2007). Manajemen Kearsipam untuk Lembaga Negara, Swasta, dan Perguruan Tinggi. Jakarta: Bumi Aksara.

http://stihpada.ac.id/ diakses pada tanggal 14 Mei 2018 pukul 20.00 Am

Madiana, G. (2004). Mengerjakan Pengarsipam Surat dan Dokumen Kantor SMK Tingkat 1. Bandung: Armico.

Nurhadi, M. A. (1983). Administrasi Pendidikan di Sekolah Jilid 1. Yogyakarta: Andi Offset.

Peraturan Pemerintah Republik Indonesia Nomor 34 Tahun 1979 tentang Penyusutan Arsip

Sutarto. (1997). Sekretaris dan Tata Warkat. Yogyakarta: Gadjah Mada University Press. 
Undang-Undang Republik Indonesia No 43 Tahun 2009 tentang Kearsipan

Wijaya, T. (2003). Tugas Sekretaris dalam Mengelola Surat dan Arsip. Jakarta: Pradnya Paramita.

Wijayanti, W. (2000). Manajemen Kantor Lembaga Pendidikan. Yogyakarta: Universitas Negeri Yogyakarta. 